\title{
Childbearing and use of oral contraceptives: impact of educational level. The Nordland Health Study
}

\author{
Bjarne K Jacobsen, Eiliv Lund, Gunnar Kvåle
}

\begin{abstract}
Study objective-The aim was to correlate the level of education to childbearing pattern and previous use of oral contraceptives in middle aged women.

Design and setting-The study was a cross sectional survey of 3608 women aged $40-42$ years in a county in northern Norway and involved $72 \%$ of all women in the age bracket living in the county. Information about childbearing and use of oral contraceptives was obtained from a self administered questionnaire.

Main results-Level of education was inversely associated with parity and positively related to age at first and last birth, to the use of oral contraceptives at any time, and particularly to the use of oral contraceptives before the first birth.

Conclusions-Women with high level of education have relatively low parity and postpone childbearing by using oral contraceptives.
\end{abstract}

Numerous studies have provided evidence that childbearing and use of oral contraceptives may influence the incidence of cancers of the breast and genital organs. ${ }^{1-3}$ Thus different reproductive behaviour in women according to educational level may influence variations in the incidence of disease between social strata of the population and have an impact on the total incidence in the population.

With this background, we investigated how level of education is related to the pattern of childbearing and to the use of oral contraceptives in a cohort of women above the usual childbearing age.

\section{Methods}

In 1988-89, all women aged 40-42 years living in the county of Nordland in the northern part of

Institute of

Community Medicine, University of Tromse, Breivika, N-9000 Tromsø, Norway B K Jacobsen E Lund

Department of Hygiene and Social Hygiene and Social
Medicine, University of Bergen, Bergen, Norway

G Kvåle

Correspondence to: Dr Jacobsen

Accepted for publication May 1991
The number of years of education was categorised into five education level groups, $<8$, $8-10,11-12,13-16$, and $>16$ years at school. The questions concerning reproductive variables were age at menarche, number of children, age at first and last delivery, and use of oral contraceptives (current use, previous use, age at first use, total duration of use, and duration of use before first delivery).

The statistical analyses, mainly cross tabulations, analysis of variance, and regression analyses, were performed by SAS. ${ }^{4}$

\section{Results}

We found a strong negative association between parity and level of education. Twenty six percent of the women with $<8$ years of education had four or more children; the corresponding figure for women with $>16$ years of education was $7 \%$. On the average, women with a relatively low level of education had 0.7 child more than women with a high level of education (table I). This difference is predominantly due to fewer children per parous woman (table I).

Women with a high level of education have their first child relatively late, on the average more than four years later than women with few years of formal education (table I). Whereas only $2 \%$ of the women with $<8$ years of education gave birth to their first child when they were more than 29 years old, this was true for $19 \%$ of women with more than 16 years of education. The relationship between level of education and age at last delivery is also positive, but less marked than for age at first delivery. In women with more than one child, educational level did not influence the mean period between births. Thus women with a high level of education have a shorter active childbearing period due to lower parity.

Current use of oral contraceptives was low $(<1 \%)$. However, previous use was more common in women with a higher level of education ( $>13$ years of education) than in women with only elementary school education ( $<8$ years of education). The positive relationship between use of oral contraceptives and level of education was found in both nulliparous and parous women.

A strong positive correlation was found between the proportion of women who had used oral contraceptives before their first delivery and level of education. However, no relationship was found between schooling and length of use of oral contraceptives before the first delivery (table II). Use of oral contraceptives before the first birth was associated with a reduction of 0.4 in the mean number of children $(p<0.0001)$. Fifty per cent of parous women who did not report use of oral contraceptives before first birth had three or more children, whereas this was the case for only one 
Table I Associations between level of education and some reproductive variables: women aged 40-42 years, Nordland Norway, 1987-88

Table II Associations between level of education and use of oral contraceptives (OC): women aged 40-42 years, Nordland, Norway, 1987-88

\begin{tabular}{|c|c|c|c|c|c|c|c|c|}
\hline $\begin{array}{l}\text { Level of } \\
\text { education } \\
\text { (years) }\end{array}$ & $\begin{array}{l}\text { Number of } \\
\text { women }\end{array}$ & $\begin{array}{l}\text { Age at } \\
\text { menarche } \\
\text { (years) }\end{array}$ & $\begin{array}{l}\text { Percent } \\
\text { nulli- } \\
\text { parous }\end{array}$ & $\begin{array}{l}\text { Number of } \\
\text { children }\end{array}$ & $\begin{array}{l}\text { Number of } \\
\text { children } \\
\text { in parous } \\
\text { women }\end{array}$ & $\begin{array}{l}\text { Age at first } \\
\text { birth } \\
\text { (years) }\end{array}$ & $\begin{array}{l}\text { Age at } \\
\text { last birth } \\
\text { (years) }\end{array}$ & $\begin{array}{l}\text { Mean period } \\
\text { between birth } \\
\text { (years) })^{1}\end{array}$ \\
\hline $\begin{array}{l}<8 \\
8-10 \\
11-12 \\
13-16 \\
>16\end{array}$ & $\begin{array}{r}258 \\
1945 \\
684 \\
553 \\
168\end{array}$ & $\begin{array}{l}13 \cdot 0 \\
13 \cdot 2 \\
13 \cdot 2 \\
13 \cdot 1 \\
12 \cdot 9\end{array}$ & $\begin{array}{r}4 \\
5 \\
5 \\
7 \\
11\end{array}$ & $\begin{array}{l}2 \cdot 8 \\
2 \cdot 6 \\
2 \cdot 4 \\
2 \cdot 2 \\
2 \cdot 1\end{array}$ & $\begin{array}{l}2 \cdot 9 \\
2 \cdot 7 \\
2 \cdot 5 \\
2 \cdot 4 \\
2 \cdot 3\end{array}$ & $\begin{array}{l}21 \cdot 1 \\
21 \cdot 7 \\
22 \cdot 5 \\
23 \cdot 9 \\
25 \cdot 7\end{array}$ & $\begin{array}{l}28 \cdot 6 \\
28 \cdot 3 \\
29 \cdot 2 \\
29 \cdot 8 \\
31 \cdot 2\end{array}$ & $\begin{array}{l}2 \cdot 5 \\
2 \cdot 4 \\
2 \cdot 5 \\
2 \cdot 4 \\
2 \cdot 4\end{array}$ \\
\hline \multicolumn{2}{|c|}{$p$ value for trend } & $0 \cdot 13$ & 0.0002 & $<0.0001$ & $<0.0001$ & $<0.0001$ & $<0.0001$ & 0.8 \\
\hline
\end{tabular}

${ }^{1}$ In women with more than one child

\begin{tabular}{|c|c|c|c|c|c|c|c|}
\hline $\begin{array}{l}\text { Level of } \\
\text { education } \\
\text { (years) }\end{array}$ & $\begin{array}{l}\text { Number of } \\
\text { women }\end{array}$ & $\begin{array}{l}\text { Percent } \\
\text { having } \\
\text { used OC }\end{array}$ & $\begin{array}{l}\text { Age at } \\
\text { first use } \\
\text { of OC } \\
\text { (years) }\end{array}$ & $\begin{array}{l}\text { Duration of } \\
\text { of } O C \\
\text { use } \\
\text { (years) }\end{array}$ & $\begin{array}{l}\text { Age when } \\
\text { stopped } \\
\text { using OC } \\
\text { (years) }\end{array}$ & $\begin{array}{l}\text { Percent using } \\
\text { OC before } \\
\text { first birth }\end{array}$ & $\begin{array}{l}\text { Duration of } O C \\
\text { use before } \\
\text { first birth } \\
\text { (years })^{1}\end{array}$ \\
\hline $\begin{array}{l}<8 \\
8-10 \\
11-12 \\
13-16 \\
>16\end{array}$ & $\begin{array}{r}258 \\
1945 \\
684 \\
553 \\
168\end{array}$ & $\begin{array}{l}39 \\
48 \\
56 \\
60 \\
58\end{array}$ & $\begin{array}{l}23 \cdot 9 \\
24 \cdot 1 \\
24 \cdot 0 \\
24 \cdot 0 \\
23 \cdot 9\end{array}$ & $\begin{array}{l}4 \cdot 5 \\
4 \cdot 5 \\
5 \cdot 1 \\
4 \cdot 6 \\
4 \cdot 1\end{array}$ & $\begin{array}{l}29 \cdot 3 \\
29 \cdot 0 \\
29 \cdot 6 \\
28 \cdot 9 \\
28 \cdot 4\end{array}$ & $\begin{array}{r}5 \\
7 \\
9 \\
22 \\
34\end{array}$ & $\begin{array}{l}1 \cdot 7 \\
2 \cdot 8 \\
3 \cdot 0 \\
2 \cdot 8 \\
3 \cdot 2\end{array}$ \\
\hline \multicolumn{2}{|c|}{$p$ value for trend } & $<0.0001$ & 0.4 & 0.9 & 0.5 & $<0.0001$ & 0.3 \\
\hline
\end{tabular}

${ }^{1}$ In women who had used OC before first birth

third of the women who did report oral contraceptive use (results not shown).

\section{Discussion}

The present study confirms and extends the results from a similar study in Tromsø, the largest town in the northern Norway. ${ }^{5}$ There are two major differences between the two studies. More information is available concerning age at delivery and use of oral contraceptives in the present study, and this study is restricted to women who, due to their age, very rarely use oral contraceptives and who are near the end of their childbearing period. In Norway, the age specific fertility rate for women aged $40-44$ years has in the last 10 years been less than 5 per 1000 women per year. ${ }^{6}$

The validity of our data concerning parity and age at first and last birth must be considered very good. However, for the information relating to level of education, age at menarche, and use of oral contraceptives, some misclassification could be expected. 78

High level of education was associated with relatively few children, delivered relatively late in the reproductive life of the woman. This is in accordance with other studies, ${ }^{59}$ and underlines the strong influence of educational level on reproductive behaviour.

The prevalence of previous oral contraceptive use reported in this questionnaire (table II) may seem high. However, short duration of use is rather common in Norway. ${ }^{10}$ The positive relationship between use of oral contraceptives at any time and level of education is in line with results from Tromsø. ${ }^{5}$ Mean duration of use and age when starting and stopping using oral contraceptives seems, however, to be unrelated to educational level. The data demonstrate a rather strong relationship between use of oral contraceptives before first birth and educational level.

Our data therefore support the notion that women with a high level of education give birth to relatively few children late in reproductive life. In order to accomplish this, women with a high level of education tend to use oral contraceptives in order to delay the first delivery.

1 Franceschi S. Reproductive factors and cancers of the breast, ovary and endometrium. Eur F Cancer Clin Oncol 1989; 25 $1933-43$.

2 Schlesselman JJ. Cancer of the breast and reproductive tract in relation to use of oral contraceptives. Contraception 1989, 40: $1-38$

3 Chilvers CED, Deacon JM. Oral contraceptives and breast cancer. Br f Cancer 1990; 61: 1-4.

4 SAS Institute Inc. SAS users guide: basics. 5 th version. Cary, NY. SAS Institute Inc, 1987 .

5 Jacobsen BK, Lund E. Level of education, use of ora consen BK, Lund E. Level of education, use of oral contraceptives, and reproductive factors:

6 Central Bureau of Statistics. Statistical yearbook of Norway 1989. Oslo: Central Bureau of Statistics Norway, 1989.

7 Bean JA, Leeper JD, Wallace RB, Sherman BM, Jagger $H$. Variations in the reporting of menstrual histories. $A m \mathcal{J}$ Epidemiol 1979; 109: 181-5.

8 Rosenberg MJ, Layde PM, Ory HW, Strauss LT, Rooks JB Rubin GL. Agreement between women's histories of oral contraceptive use and physician records. Int $\mathcal{f}$ Epidemiol 1983; 12: 84-7.

9 Noack T, Ostby L. Fertility among Norwegian women. Results from the fertility survey 1977. Oslo: Central Bureau of Statistics of Norway, 1981.

10 Grimsmo A. Bruk av prevensjon hos voksne. In: Walløe $\mathrm{L}$ ed Seksualitet, familieplanlegging og prevension $i$ Norge. Oslo: Universitetsforlaget, 1978: 27-55 (in Norwegian). 